「農業と繊維・高分子」持集

\title{
農業用スパンボンド不織布
}

\section{岩田喜 登}

スパンボンド不織布とは, 合成繊維（合繊）の紡系工 程と繊維ウェブ形成工程及びボンディング工程を連続に 持つことにより製造される合縺長瀻維不織布であり, 米 国 Du Pont 社の特許（特公昭37-4993，1956年出願）に よって世に紹介された。企業化は, 同じく米国 Du Pont 社が1965年に“Reemay”（ポリエステル）を発表したの が最初であり，その後1970年代にかけて欧米の合織メー カーや化学メーカーで, 我国では石油化学メーカーや合 織メーカーで相次いで商業生産が開始された。我国の生 産量推移を見ると, 1973年は約 3 千万 $\mathrm{m}^{2}, 1986$ 年は44千 万 $\mathrm{m}^{2}$ ，1992年には119千万 $\mathrm{m}^{2}$ と急速な拡大がなされてい るが、農業資材用途もその一端を担っている。

スパンボンド不織織布には，1)䄉維が連続したフィ ラメントからなり, 強力が高い。2）適度な保温性, 通 気性, 通水性, 透湿性が有り, 同時に吸湿性, 保水性も 得られる。3) 素材（ポリエステル, ナイロン, ポリプ ロピレン,これらの複合等), 目付, 色などを多様に組 み合わせて生産ができ，必要な透光性，遮光性が得られ る，などの基本的特徴があり，ハウスの内張用，遮光 · 遮熱用, べたがけ用, 水稲育苗用, お茶の防霜用, 給排
水用など, 被覆資材や下敷資材として使用されている。

\section{1. ハウスの内張用}

八ウスなどの施設栽培は, 1973年の石油ショック以降, 如何にして暖房用燃料を節約するかが課題となり, 内張 カーテンの多層化が推進されてきた。スパンボンド不織 布が本格的に農業用に使用されたのはこの時期からであ る。内張カーテンにフィルムを使用すると, 保温効果は 優れるが, 密閉度が上がり, 夜間から明け方にかけて温 度が下がってハウス内が過湿になり易く，水蒸気がフィ ルム面で凝縮して水滴になり，落下して作物を濡らす。 また, 外層材面からの凝縮落下水滴がカーテンの上に溜 まり、いわゆる「金魚鉢」になる。これらは, 作物の品 質を低下し，特有病気の発生現因になるばかりでなく, 色々な面で作業環境を悪化させる。

スパンボンド不織布は，一般にはポリエステル（40～ $\left.50 \mathrm{~g} / \mathrm{m}^{2}\right)$ が使用される。内張にすると表 1 のように熱 貫流率が低く保温性があり，更に保水，通水の性能によ って，上記の表面凝縮水や外層材からの落下水滴を吸収 し保水する。従って，八ウス内の過剩水蒸気を吸収し湿

表 1 ポリエステルスパンボンド不織布の内張カーテン熱貫流率及び性能

\begin{tabular}{|c|c|c|c|c|c|}
\hline \multirow{2}{*}{$\begin{array}{c}\text { ブランク } \\
\text { (カーテンなし) }\end{array}$} & \multicolumn{2}{|c|}{ 一層の場合 } & \multicolumn{2}{|c|}{ 二層の場合 } \\
\cline { 3 - 6 } & ラブシート & ビニール & $\mathrm{PE} / \mathrm{PE}$ & $\mathrm{PE} /$ ブシート \\
\hline 熱貫流率 & 4.19 & 2.70 & 2.53 & 1.88 & 1.68 \\
\hline
\end{tabular}

(熱貫流率： $\mathrm{Kcal} / \mathrm{m}^{2} \mathrm{hr}{ }^{\circ} \mathrm{C}$ ，ラブシート：ポリエステルスパンボンド不織布)

\begin{tabular}{|c|c|c|c|c|c|c|}
\hline $\begin{array}{c}\text { スパンボンド } \\
\text { 不織布名 }\end{array}$ & $\begin{array}{c}\text { 目付 } \\
\mathrm{g} / \mathrm{m}^{2}\end{array}$ & $\begin{array}{c}\text { 保水率 } \\
\%\end{array}$ & $\begin{array}{c}\text { 保水量 } \\
\mathrm{g} / \mathrm{m}^{2}\end{array}$ & $\begin{array}{c}\text { 透水率 } \\
\%\end{array}$ & $\begin{array}{c}\text { 遮光率 } \\
\%\end{array}$ & $\begin{array}{c}\text { 通 気 度 } \\
\mathrm{cc} / \mathrm{cm}^{3} / \mathrm{sec}\end{array}$ \\
\hline $20407 \mathrm{FLD}$ & 40 & 130 & 52 & 25 & 50 & 85 \\
\hline $20507 \mathrm{FLD}$ & 50 & 130 & 65 & 20 & 55 & 55 \\
\hline
\end{tabular}

(ユニチカカタログ)

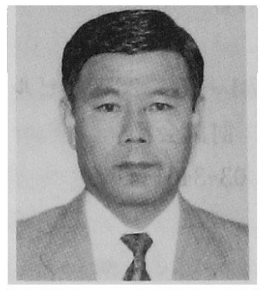

Spunbonded Nonwovens for Agricultural Use

筆者紹介 YOSHINORI IWATA

Spunbonded Fabrics Production Development Dept., Spunbonded Fabrics Division, Unitika Ltd. ユニチカ株式会社スパンボンド事業本部スパンボンド生産開発部, 主管

筆者は，スパンボンドの開発に携わっておられ，魚釣り，家侹菜園を趣味としておられる。

本稿ではスパンボンド不織布の特徽をたくみに利用した農業分野における応用例について解説していた たいた。 
表 2 凝縮水量の計算基礎

\begin{tabular}{|c|c|c|c|c|}
\hline $\begin{array}{l}\text { 温度 } \\
\\
\text { C } \\
\text { (1) }\end{array}$ & $\begin{array}{c}\text { 関係洫度 } \\
\text { \% RH } \\
\text { (2) }\end{array}$ & $\begin{array}{l}\text { 湿 } \\
\text { 水g/Kg乾空気 } \\
\text { (3) }\end{array}$ & $\begin{array}{c}\text { 湿り及び飽和 } \\
\text { 比 容 } \\
\mathrm{m}^{3} / \mathrm{Kg} \text { 乾空氛 } \\
\text { (4) }\end{array}$ & $\begin{array}{l}\text { 水蒸気 } \\
\text { 水 } g / \mathrm{m}^{3} \\
(3) \div \text { (4) }\end{array}$ \\
\hline 25 & 100 & 20.0 & 0.87 & 23.0 \\
\hline 8 & 100 & 7.0 & 0.80 & 8.8 \\
\hline
\end{tabular}

低温度湿度図表（基萑：全压760 $\mathrm{mmHg} ， 1 \mathrm{Kg}$ 一乾空氛）

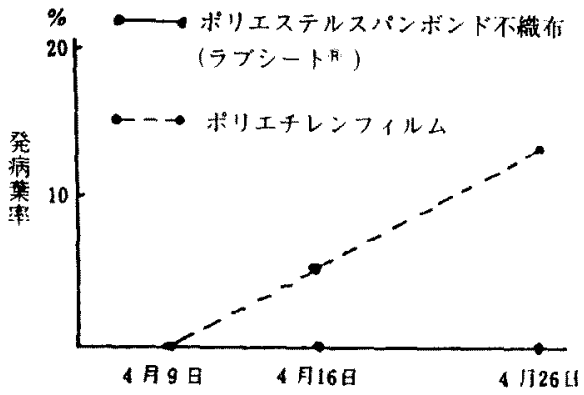

图1内部被嗄資材とキュウリベと病の発生

(神漈川県園芸試験場)

度を下げる効果があり，早朝の霧や霰（もや）の発生を 押已之，作物への水滴落下もなくなる。例之代高さ $3 \mathrm{~m}$ のハウス内で, 夕方温度 $25^{\circ} \mathrm{C}$, 湿度 $100 \% \mathrm{RH}$ が明け力 に8 Cになると，水蒸気量か $23 \mathrm{~g} / \mathrm{m}^{3}$ から $9 \mathrm{~g} / \mathrm{m}^{3} に な り ，$ $1 \mathrm{~m}^{2}$ 当たり $42 \mathrm{~g}$ の水が凝縮する事になる(表2)。これ はスパンボンド不織布の保水可能量（表 1 ，目付 40 g $\left(\mathrm{m}^{2}\right)$ O81\%になり，十分保水できることになる。また， 吸収された水分が織維開で水膜を作り，対流索㧕え，保 温牲を上げる。トマト、キュウリ、ピーマンなどの果菜 類は過湿による病気発生が, バラ, カーネーション,な どの花きでは水滴落下による品質低下が起こり易い。こ の問題を解決するため，積極的にスパンボンド不織布を
下層カーテンに使用するケースが多い。四1はキュウリ のベと病発生率の比較であり，スパンボンド不織布では 殆ど発生していないのが判る。

\section{2.ベたがけ用}

作物の上に直接被覆する方法で，生育促進，品翼问上， 增取, 発芽向上, 上境乾燥防止，防出，防鳥，防霜，防 風等の効果が確認されている。被䇥材には割䄉維，不織 布，寒令紗などが使われているが，1980年代前半に，軽 く(15 - 20 g/ $\left.\mathrm{m}^{2}\right)$ ，透光性に優れ(透光妓80-90\%)， 安価なスパンボンド不織布が開発されてからスパンボン ド不織布の伸びが著しく，急速に全国的に使用される上 うになった。現在のスパンボンド不織布は全ての采件を 满たしているわけではないが，特性面，洒格面で他の资 材に比心゙てバランスが取れて招り，レタス，白菜，ホー レンソウなどの葉菜類から大根，人参，ゴボウなどの根 菜類，更にはイモ，タマネギ，タバコなどの大面皘栽培 にまで対象作物の広がりを可能にした。べたがけが作物 の生育に及ばす影䔩については，ベたがけ下の環境が通 常の露地や施設内とどのように異なるが解析すること であるが，狭い空間であり，周辺環境にも影響さ机るた め信頼できるデー夕はなく，明らかにされていないが， 奏際の使用例と効果を次に記す。

(1)トンネル内ベたがけと無被覆との温度比較（表 3)： 全期間を通じてべたがけ区の方が $1-3{ }^{\circ} \mathrm{C}$ 高い。 (2)軟弱野菜の露地べたがけ（表 4)：何れの野莱も、1 株重壆が無被輀区に比べ2〜5倍重くなっている。 (3)露地べたがけ，小松菜の虫害軽減試験（写真1）：播 種した時からべたがけ被覆することで，虫害（コナガ） を軽隇する効果があった。薬剤散布回数を減らすことが でき，より安全な生鮮野莱の供給，都市近郊で蹴境改善， 薬戍散布作菜者の健康の面から安注目されている。

表 3 温度調查（12月1日播種）(埼玉目園望試験場鶴ヶ島洪積畑支場）

\begin{tabular}{|c|c|c|c|c|c|c|c|c|c|}
\hline & \multicolumn{3}{|c|}{ 12月 24 日 -1 月 7 日 } & \multicolumn{3}{|c|}{ 1月 8 日一 1月 20 日 } & \multicolumn{3}{|c|}{ 1月 22 日 -2 月 10 日 } \\
\hline & 気 & 温 & 平均 & 気 & 温 & 平均 & 気 & 温 & 平均 \\
\hline & 最高 & 最低 & 地温 & 最高 & 最低 & 地温 & 最高 & 最低 & 地混 \\
\hline 無被澓区 & $15.5^{\circ} \mathrm{C}$ & $0.4^{\circ} \mathrm{C}$ & $7.9^{\circ} \mathrm{C}$ & $18.9^{\circ} \mathrm{C}$ & $-2.6^{\circ} \mathrm{C}$ & $7.0^{\circ} \mathrm{C}$ & $-{ }^{\circ} \mathrm{C}$ & $-0.6^{\circ} \mathrm{C}$ & $-{ }^{\circ} \mathrm{C}$ \\
\hline ハだがけ区 & 18.0 & 2.0 & 9.0 & 20.3 & 0.7 & 8.1 & 15.8 & 1.3 & 7.1 \\
\hline
\end{tabular}

表 4 軟弱野菜の露地べたがけ（1株重量，g)

\begin{tabular}{|c|c|c|c|c|c|}
\hline & 小松菜 & ホウレンソウ & ターサイ & シュンギク & 東京あおな \\
\hline ベたがけ区 & 16.5 & 4.4 & 9.1 & 1.6 & 11.2 \\
\hline 無被覆区 & 6.1 & 2.0 & 1.6 & 0.3 & 2.6 \\
\hline
\end{tabular}

播櫄・被㠅11月22日 調查12月10日

(11梨县総含蔍試) 

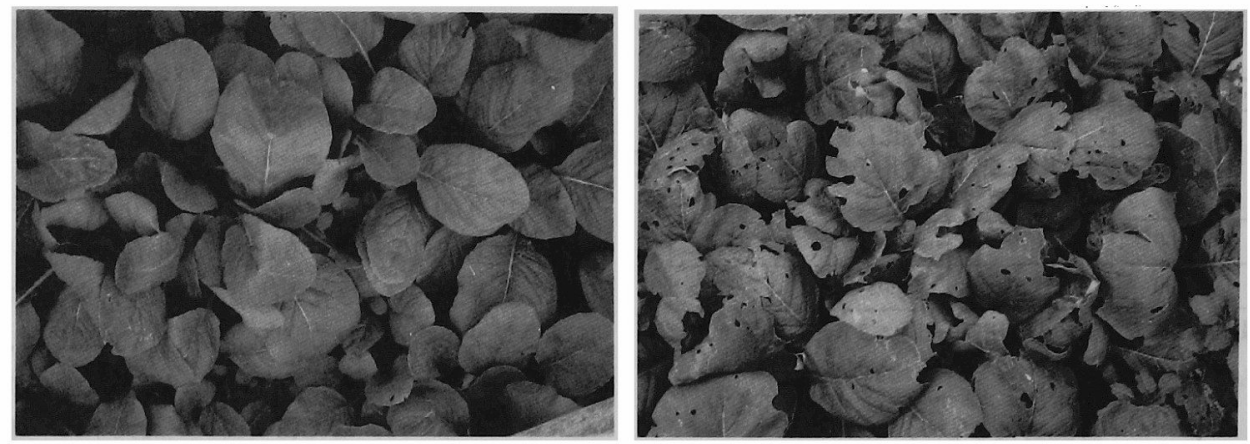

写真1 スパンボンド不織布 (パスライト ${ }^{\circledR}$ ) のベたがけによる防虫害効果

不織布使用 (左)，末使用（右）

\section{3. 底面給排水マット}

鉢物栽培のシクラメンやベゴニア等の花き類は, 花や 葉に水滴が付着すると退色や病気が発生し易いため, 一 鉢毎に根本に灌水しなければならず，灌水作業は多大の 労力と時間を要し, 園芸農家にとって大きな負担となっ ている。スパンボンド不織布の通水性, 保水性, 通気性, 破れにくい, 根を透しにくい等の機能を利用して底面給 排水方式が開発されて, 省力化, 作物育成の均一化, 高 品質化ができるようになり，経営規模の拡大も可能にな ってきた。現在使用されているマットは, ポリエステル スパンボンド不織布のニードルパンチタイプである。図 2 のように三層構造で使用される場合が多く，ベンチの 上に遮水シートを敷き，その上に給排水マットを，更に 鉢底から根の侵入を防ぐ防根シートを敷く方法が一般的 である。図 3 は給排水マットに使用されているスパンボ ンド不織布の吸水拡散性能であるが, 一個所で給水すれ ば広範囲に拡散し，また約 $10 \mathrm{~cm}$ 高の枠があってもこれを 越えて拡散，給排水が可能であることが判る。

以上に述べたものは，ほんの一例に過ぎないが，スパ ンボンド不織布の持つ特性を生かして, 新しい用途の開 発が進んでいる。特に作物の早取り, 高品質生産を目的 とするのに加えて, 如何にして労働コストを低減するか

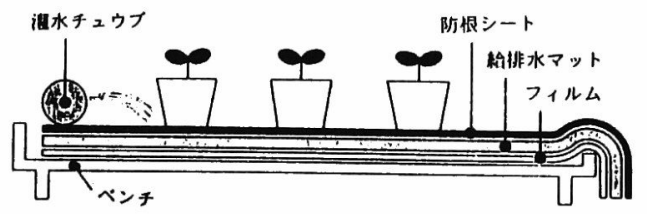

図 2 底面給排水マットの敷設例

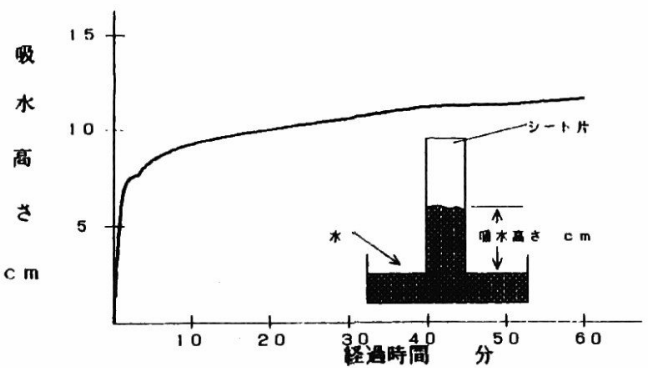

図 3 底面給排水マットのバイレック試験結果

(吸水高さ)

が重要ポイントになってきている。作物に被覆する従来 の形に対し, 鉢の下に直接敷く，地面に直接敷く，根の 部分を包む等の根域制御栽培分野も注目されてきた。ま た，保水性を生かしたまま遮熱，遮光性を有するシート として, ポリエステルスパンボンド不織布にポリエチレ ンフィルムや酢ビフィルムをラミネートした複合シート, アルミ蒸着加工したシートも開発され実用化が始まって いる。このようにスパンボンド不織布は用途開発だけで なく, 素材そのものの改良, 開発も進められ, 今後の展 開が大いに期待されている。

\section{参考文献}

1 ）合縺長䋐維不織布ハンドブック, 日本化学緎維協会

2）施設園芸ハンドブック，(財)日本施設園芸協会

3 ）べたがけの現状と考察, 日本農業気象学会施設園芸 研究部, 日本農園芸資材研究会

4) 伊達隆一：緎維工学 Vol. 44, No. 11 (1991)

(平成 5 年 5 月 10 月受理) 